\title{
Clinical and Histopathological Features and Potential Pathological Mechanisms of Skin Lesions in COVID-19: Review of the Literature
}

\author{
Gürkan Kaya ${ }^{1, *}$, Aysin Kaya ${ }^{2}$ and Jean-Hilaire Saurat ${ }^{2}$ \\ 1 Departments of Dermatology and Clinical Pathology, University Hospital of Geneva, \\ 1205 Geneva, Switzerland \\ 2 Department of Clinical Pharmacology and Toxicology, University of Geneva, 1205 Geneva, Switzerland; \\ Aysin.Kaya@unige.ch (A.K.); Jean.Saurat@unige.ch (J.-H.S.) \\ * Correspondence: gkaya@hcuge.ch
}

Received: 24 June 2020; Accepted: 29 June 2020; Published: 30 June 2020

\begin{abstract}
In recent weeks, several reports have emerged of skin lesions with different clinical presentations in COVID-19 cases. All dermatologists should be aware of these cutaneous lesions, which may be early clinical symptoms of infection. We reviewed the literature on cutaneous manifestations in the PubMed database from December 2019 and June 2020. From the cases described as case reports or series in 57 recent articles, it appears that skin lesions (i) are highly varied, (ii) may not be related to the severity of the condition and (iii) resolve spontaneously in a few days. The frequency of these lesions in COVID-19 patients varies between $1.8 \%$ and $20.4 \%$. The major clinical forms described were maculopapular eruptions, acral areas of erythema with vesicles or pustules (pseudochilblain), urticarial lesions, other vesicular eruptions and livedo or necrosis. The lesions were mainly localized in the trunk and extremities. The majority of patients were male, aged between 4.5 and 89 years. A minority of the patients were children presenting with acral, chilblain-like lesions, papulo-vesicular eruptions or Kawasaki disease-like pediatric inflammatory multisystem syndrome. The mean duration of the lesions was a few days, but some lasting as little as 20 min and others as long as four weeks have been reported. The mean latency time in the majority of cases was between 1 and 14 days; however, in some patients, lesions appeared 2 to 5 days before the onset of COVID-19 symptoms. The histopathological features of these lesions also vary, corresponding to the diversity of clinical manifestations. These features underline the nature of epidermal and dermal vascular lesions-and in severe cases, microvascular injury and thrombosis-associated with COVID-19, and provide important clues to their pathological mechanisms.
\end{abstract}

Keywords: skin lesions; COVID-19; SARS-CoV-2; histopathology

\section{Introduction}

In recent weeks, there have been several published reports of COVID-19 cases with skin lesions with different clinical presentations; all dermatologists should be aware of these clinical signs. In patients with COVID-19, aggravation of previous skin lesions have been noted, and allergic reactions to the different medications used for treatment may occur. However, recently, there have been reports of skin lesions that may correspond to cutaneous manifestations of SARS-CoV-2 [1].

The characteristics of skin lesions in patients with COVID-19, as described recently in case reports or case series, are summarized in the Table 1 [2-58]. According to these publications, in which the majority of reported patients had Fitzpatrick skin types I-III [59], the skin manifestations of COVID-19 are highly varied and nonspecific, are not necessarily related to the severity of the condition and resolve spontaneously in a few days. 
Table 1. Clinical and histopathological characteristics of skin lesions in COVID-19 patients reported in 57 publications.

\begin{tabular}{|c|c|c|c|c|c|c|c|c|c|}
\hline \multirow{2}{*}{$\mathrm{Nb} \&$ Sex } & \multirow{2}{*}{ Age } & \multirow{2}{*}{ Clinical Features } & \multirow{2}{*}{ Localization of Skin Lesions } & \multirow{2}{*}{ Time from 1st Symptoms } & \multirow{2}{*}{ Mean Duration } & \multirow{2}{*}{ Histopathological Features } & \multicolumn{2}{|c|}{ SARS-CoV-2 RT-PCR } & \multirow{2}{*}{ Ref } \\
\hline & & & & & & & Swab & Skin Biopsy & \\
\hline $1 \mathrm{~F}$ & $8 \mathrm{y}$ & Papulovesicular skin eruption & Trunk & -5 days & 7 days & No biopsy & positive & ND & [7] \\
\hline $1 \mathrm{M}$ & $57 \mathrm{y}$ & Exanthem & Erythematous crusted papules & -2 days & 10 days & $\begin{array}{l}\text { Superficial perivascular vesicular dermatitis, focal } \\
\text { acantholytic suprabasal clefts, dyskeratotic and } \\
\text { ballooning, herpes-like keratinocytes and swollen vessels } \\
\text { with dense lymphocyte infiltration mixed with rare } \\
\text { eosinophils in the dermis. }\end{array}$ & positive & ND & [8] \\
\hline $1 \mathrm{~F}$ & $27 y$ & Urticarial erythematous plaques & Face and acral invol- vement & -2 days & ND & No biopsy & positive & ND & [12] \\
\hline $1 \mathrm{M}$ & $68 \mathrm{y}$ & Painful blisters & Right side of the right loin & -2 days & ND & No biopsy & positive & ND & [52] \\
\hline $1 \mathrm{~F}$ & $43 y$ & \multirow{2}{*}{$\begin{array}{l}\text { Dusky red, nonpruritic, } \\
\text { nonblanching dyschromia. }\end{array}$} & \multirow{2}{*}{ Periorbital skin } & \multirow{2}{*}{-2 days } & \multirow{2}{*}{ A few days } & \multirow{2}{*}{ No biopsy } & \multirow{2}{*}{ positive } & \multirow{2}{*}{ ND } & \multirow{2}{*}{ [54] } \\
\hline $1 \mathrm{M}$ & $50 \mathrm{y}$ & & & & & & & & \\
\hline $1 \mathrm{~F}$ & $39 y$ & \multirow[b]{2}{*}{ Urticarial rash } & Forearms & -2 days & \multirow{2}{*}{ ND } & \multirow{2}{*}{ No biopsy } & \multirow{2}{*}{ positive } & \multirow{2}{*}{ ND } & \multirow{2}{*}{ [27] } \\
\hline $1 \mathrm{M}$ & $71 \mathrm{y}$ & & Entire body & -a few days & & & & & \\
\hline $1 \mathrm{~F}$ & $39 \mathrm{y}$ & Urticarial rash & Trunk, thigh and other areas & -1 day & ND & No biopsy & ND & ND & [46] \\
\hline $1 \mathrm{~F}$ & $50 \mathrm{y}$ & \multirow{2}{*}{$\begin{array}{l}\text { Erythematous annular and } \\
\text { irregular wheals. }\end{array}$} & \multirow{2}{*}{$\begin{array}{l}\text { Shoulders, elbow, } \\
\text { knee and buttocks }\end{array}$} & \multirow{2}{*}{ Onset } & \multirow{2}{*}{2 days } & \multirow{2}{*}{ No biopsy } & \multirow{2}{*}{ ND } & \multirow{2}{*}{ ND } & \multirow{2}{*}{ [47] } \\
\hline $1 \mathrm{~F}$ & $20 \mathrm{y}$ & & & & & & & & \\
\hline $\begin{array}{c}17 \mathrm{M} \\
3 \mathrm{~F}\end{array}$ & mean: $51 \mathrm{y}$ & $\begin{array}{c}\text { Sebopsoriasis }(n=1) \text {, facial } \\
\text { herpes }(n=1) \text {, exanthem }(n=9), \\
\text { acral vasculitic eruption }(n=6), \\
\text { urticaria }(n=2) \text { and } \\
\text { varicelliform rash }(n=1) .\end{array}$ & $\begin{array}{l}\text { Face, acral sites and } \\
\text { entire body }\end{array}$ & $\begin{array}{l}\text { Onset }(n=2) \text {, } \\
\text { later }(n=18) .\end{array}$ & ND & Exanthem: perivascular dermatitis and vasculitis. & positive & ND & [38] \\
\hline $1 \mathrm{M}$ & $58 \mathrm{y}$ & $\begin{array}{l}\text { Erythematous macules arranged } \\
\text { in a morbilliform pattern. }\end{array}$ & $\begin{array}{l}\text { Legs, thighs, forearms, arms, } \\
\text { shoulders, back, chest and } \\
\text { abdomen }\end{array}$ & 1 day & 6 days & No biopsy & positive & ND & [23] \\
\hline $1 \mathrm{M}$ & $13 \mathrm{y}$ & $\begin{array}{l}\text { Erythemato-violaceous, } \\
\text { rounded lesions. }\end{array}$ & $\begin{array}{l}\text { Plantar surface of the first toe } \\
\text { and dorsal surface of the } \\
\text { second toe on the right and left } \\
\text { feet, respectively }\end{array}$ & 2 days & Around 10 days & No biopsy & not done & ND & [22] \\
\hline $\begin{array}{c}16 \mathrm{M} \\
6 \mathrm{~F}\end{array}$ & mean: $60 \mathrm{y}$ & $\begin{array}{l}\text { Varicella-like papulovesicular } \\
\text { exanthem. }\end{array}$ & Trunk and limbs & 3 days & 8 days & $\begin{array}{l}\text { Vacuolar degeneration of the basal layer with } \\
\text { multinucleate, hyperchromatic keratinocytes and } \\
\text { dyskeratotic cells. Absence of inflammatory infiltrate. }\end{array}$ & positive & ND & [21] \\
\hline $1 \mathrm{~F}$ & $59 \mathrm{y}$ & Erythematous & Arms, trunk and lower limbs & 3 days & 5 days & $\begin{array}{l}\text { Superficial perivascular dermatitis with slight } \\
\text { lymphocytic exocytosis, swollen thrombosed vessels } \\
\text { with neutrophils, eosinophils and nuclear debris. }\end{array}$ & positive & ND & [8] \\
\hline $1 \mathrm{M}$ & $16 \mathrm{y}$ & $\begin{array}{l}\text { Erythemato-edematous, partially } \\
\text { eroded macules and plaques. }\end{array}$ & Dorsal aspects of the fingers & 3 days & ND & $\begin{array}{l}\text { Edema of the papillary dermis, superficial and deep } \\
\text { lymphocytic infiltrate in a perivascular and strong } \\
\text { perieccrine pattern. }\end{array}$ & positive & ND & [40] \\
\hline $1 \mathrm{~F}$ & $64 \mathrm{y}$ & SDRIFE-like erythematous rash. & $\begin{array}{l}\text { Antecubital fossa, trunk and } \\
\text { axillary folds }\end{array}$ & 4 days & 5 days & No biopsy & positive & ND & [19] \\
\hline $1 \mathrm{~F}$ & $56 \mathrm{y}$ & \multirow{2}{*}{$\begin{array}{l}\text { Painful ulcers with irregular } \\
\text { margins and varying sizes in red } \\
\text { and nonhemorrhagic } \\
\text { background. }\end{array}$} & Hard palate & 5 days & \multirow{2}{*}{7 days } & Siffuse edema with mucosal desquamation along with & positive & $\mathrm{ND}$ & [55] \\
\hline $1 \mathrm{M}$ & $75 \mathrm{y}$ & & Anterior of the tongue & ND & & $\begin{array}{l}\text { granulation and ulceration under the mucosa with } \\
\text { invasion of mononuclear cells with large and } \\
\text { glassy nuclei. }\end{array}$ & & & \\
\hline
\end{tabular}


Table 1. Cont.

\begin{tabular}{|c|c|c|c|c|c|c|c|c|c|}
\hline \multirow{2}{*}{$\mathrm{Nb} \& \mathrm{Sex}$} & \multirow{2}{*}{ Age } & \multirow{2}{*}{ Clinical Features } & \multirow{2}{*}{ Localization of Skin Lesions } & \multirow{2}{*}{ Time from 1st Symptoms } & \multirow{2}{*}{ Mean Duration } & \multirow{2}{*}{ Histopathological Features } & \multicolumn{2}{|c|}{ SARS-CoV-2 RT-PCR } & \multirow{2}{*}{ Ref } \\
\hline & & & & & & & Swab & Skin Biopsy & \\
\hline $1 \mathrm{M}$ & $66 \mathrm{y}$ & $\begin{array}{l}\text { Papules with pseudovesicular } \\
\text { aspect and superficial crusts }\end{array}$ & Trunk & 6 days & 10 days & $\begin{array}{l}\text { Extensive epidermal necrosis with acantholysis and large } \\
\text { multinucleated keratinocytes with ballooning } \\
\text { degeneration in the superficial dermis, a dense } \\
\text { perivascular lymphocytic infiltrate with some } \\
\text { extravasated erythrocytes, neutrophils and eosinophils, } \\
\text { dermal vessels displaying endothelial swelling with } \\
\text { lymphocytic vasculitic alterations and endotheliitis in the } \\
\text { absence of fibrinoid necrosis or thrombosis. }\end{array}$ & positive & negative & [43] \\
\hline $1 \mathrm{~F}$ & $32 \mathrm{y}$ & Urticarial rash & Trunk and limbs & 6 days & ND & $\begin{array}{l}\text { Perivascular infiltrate of lymphocytes, some eosinophils } \\
\text { and upper dermal edema. }\end{array}$ & ND & ND & [4] \\
\hline $1 \mathrm{M}$ & $20 \mathrm{y}$ & $\begin{array}{l}\text { Diffuse, morbilliform, maculo- } \\
\text { papular rash. }\end{array}$ & $\begin{array}{l}\text { Trunk and extremities, sparing } \\
\text { the face }\end{array}$ & 6 days & ND & No biopsy & positive & ND & [14] \\
\hline $1 \mathrm{~F}$ & $55 \mathrm{y}$ & \multirow{2}{*}{$\begin{array}{l}\text { Small, monomorphic vesicles of } \\
2-3 \text { mm diameter, often } \\
\text { excoriated at their top. }\end{array}$} & \multirow[b]{2}{*}{ Trunk } & \multirow[b]{2}{*}{6 days } & 11 days & \multirow{2}{*}{$\begin{array}{l}\text { Scantholysis, intraepidermal vesicle, suprabasal clefts, } \\
\text { prominent, "pomegranate-like" dyskeratosis, suspected } \\
\text { nuclear viral inclusions and multinucleated cells. }\end{array}$} & \multirow{2}{*}{ positive } & \multirow[b]{2}{*}{ ND } & \multirow[b]{2}{*}{ [58] } \\
\hline $1 \mathrm{M}$ & $55 \mathrm{y}$ & & & & 22 days & & & & \\
\hline $1 \mathrm{~F}$ & $89 \mathrm{y}$ & Macules & Trunk and arms & 7 days & 8 days & $\begin{array}{l}\text { Superficial and deep perivascular dermatitis with cuffs of } \\
\text { lymphocytes surrounding blood vessels in a } \\
\text { vasculitic pattern. }\end{array}$ & positive & ND & [8] \\
\hline $\begin{array}{l}5 \mathrm{M} \\
1 \mathrm{~F}\end{array}$ & mean: $15 \mathrm{y}$ & $\begin{array}{l}\text { Red to violaceous macules and } \\
\text { dusky, purpuric plaques. }\end{array}$ & $\begin{array}{l}\text { Mid- and distal- aspects of } \\
\text { the toes }\end{array}$ & 7 days & ND & $\begin{array}{l}\text { Superficial and deep perivascular and perieccrine } \\
\text { lymphocytic infiltrate with junctional vacuolar change } \\
\text { and lymphocytic vasculitis, with no evidence of } \\
\text { thrombosis in the vessels. }\end{array}$ & negative & ND & [33] \\
\hline $1 \mathrm{M}$ & $81 \mathrm{y}$ & $\begin{array}{l}\text { Petechial lesions initially, then } \\
\text { hemorrhagic bullae and } \\
\text { necrotic plaques. }\end{array}$ & Fingers and toes & 7 days & ND & $\begin{array}{l}\text { Partial-thickness necrosis of the superficial portion of the } \\
\text { epidermis and a mild inflammatory infiltrate in the } \\
\text { papillary dermis composed predominantly of } \\
\text { neutrophils, red blood cell extravasation and small vessel } \\
\text { vasculitis with no thrombi, papillary dermal edema or } \\
\text { extension of the infiltrate to the deep dermis. }\end{array}$ & negative & ND & [34] \\
\hline 15 & ND & skin rash & ND & 7 days & ND & No biopsy & ND & ND & [17] \\
\hline $1 \mathrm{M}$ & $67 \mathrm{y}$ & \multirow{2}{*}{$\begin{array}{l}\text { Transient unilateral livedo } \\
\text { reticularis }\end{array}$} & Right anterior thigh & 7 days & $19 \mathrm{~h}$ & \multirow{2}{*}{ No biopsy } & \multirow{2}{*}{ positive } & \multirow{2}{*}{ ND } & \multirow{2}{*}[20]{} \\
\hline $1 \mathrm{~F}$ & $47 \mathrm{y}$ & & Right leg & 10 days & $20 \mathrm{~min}$ & & & & \\
\hline 1 & ND & $\begin{array}{l}\text { Sigitate papulosquamous } \\
\text { eruption }\end{array}$ & $\begin{array}{l}\text { Periumbilical area, lateral side } \\
\text { of the trunk and thighs }\end{array}$ & 8 days & 7 days & $\begin{array}{l}\text { Mild diffuse spongiosis in the epidermis and rounded } \\
\text { spongiotic vesicles containing aggregates of lymphocytes } \\
\text { and Langerhans cells, as well as mild papillary edema } \\
\text { and lymphohistiocytic infiltrate in the dermis. }\end{array}$ & positive & negative & [30] \\
\hline $\begin{array}{l}71 \mathrm{M} \\
61 \mathrm{~F} \\
\end{array}$ & mean: $19.9 \mathrm{y}$ & $\begin{array}{l}\text { Chilblain-like }(n=95) \text {, erythema } \\
\text { multiforme-like }(n=37)\end{array}$ & Hands and feet & 9.2 days & 8.7 days & No biopsy & $\begin{array}{l}\text { positive } \\
(2 \text { in 11) }\end{array}$ & ND & [5] \\
\hline $1 \mathrm{~F}$ & $84 \mathrm{y}$ & $\begin{array}{l}\text { Erythemato-purpuric, } \\
\text { millimetric, coalescing macules. }\end{array}$ & Periaxillary area & 11 days & ND & No biopsy & ND & ND & [15] \\
\hline $1 \mathrm{M}$ & $32 \mathrm{y}$ & Retiform purpura & Buttocks & 11 days & \multirow{3}{*}{ ND } & \multirow{3}{*}{$\begin{array}{l}\text { Thrombogenic vasculopathy accompanied by striking } \\
\text { and extensive deposition of C5b- } 9 \text { and C4d within } \\
\text { the microvasculature. }\end{array}$} & \multirow{3}{*}{ positive } & \multirow{3}{*}{ ND } & \multirow{3}{*}{ [18 } \\
\hline $1 \mathrm{~F}$ & $66 y$ & Dusky purpuric patches & Palms and soles & 11 days & & & & & \\
\hline $1 \mathrm{~F}$ & $40 y$ & Livedo racemosa & Chest, legs and arms & ND & & & & & \\
\hline $1 \mathrm{M}$ & ND & $\begin{array}{l}\text { Erythematous and edematous } \\
\text { plaques with a purpuric center. }\end{array}$ & Buttocks & 12 days & ND & $\begin{array}{l}\text { Perivascular neutrophilic inflammation and blood } \\
\text { extravasation in the dermis with endothelial swelling, } \\
\text { necrosis and fibrin deposition. }\end{array}$ & ND & ND & [49] \\
\hline
\end{tabular}


Table 1. Cont.

\begin{tabular}{|c|c|c|c|c|c|c|c|c|c|}
\hline \multirow{2}{*}{$\mathrm{Nb} \& \mathrm{Sex}$} & \multirow{2}{*}{ Age } & \multirow{2}{*}{ Clinical Features } & \multirow{2}{*}{ Localization of Skin Lesions } & \multirow{2}{*}{ Time from 1st Symptoms } & \multirow{2}{*}{ Mean Duration } & \multirow{2}{*}{ Histopathological Features } & \multicolumn{2}{|c|}{ SARS-CoV-2 RT-PCR } & \multirow{2}{*}{ Ref } \\
\hline & & & & & & & Swab & Skin Biopsy & \\
\hline $1 \mathrm{~F}$ & $28 y$ & $\begin{array}{l}\text { Erythematous-yellowish papules } \\
\text { and plaques. }\end{array}$ & Both heels & 13 days & ND & No biopsy & positive & $\mathrm{ND}$ & [3] \\
\hline $1 \mathrm{M}$ & $26 y$ & $\begin{array}{l}\text { Erythematous, slightly } \\
\text { edematous eruption. }\end{array}$ & Malar region, neck and ears & 14 days & 6 days & No biopsy & not done & ND & {$[13]$} \\
\hline $1 \mathrm{~F}$ & $60 \mathrm{y}$ & $\begin{array}{l}\text { Distally convex, half } \\
\text { moon-shaped red band } \\
\text { surrounding the distal margin of } \\
\text { the lunula. }\end{array}$ & All fingernails & 14 days & $\begin{array}{l}\text { Still present after } \\
1 \text { month }\end{array}$ & No biopsy & positive & ND & [37] \\
\hline $1 \mathrm{~F}$ & $62 \mathrm{y}$ & $\begin{array}{l}\text { Ssymptomatic, nonitchy rash } \\
\text { consisting of livedoid } \\
\text { patches/livedoid macules. }\end{array}$ & $\begin{array}{l}\text { Back, abdomen and } \\
\text { face/bilateral periorbital skin, } \\
\text { back of the nose and } \\
\text { frontal region }\end{array}$ & 14 days & $24 \mathrm{~h}$ & No biopsy & positive & ND & [53] \\
\hline $1 \mathrm{~F}$ & $60 \mathrm{y}$ & Urticarial eruption & ND & 16 days & ND & $\begin{array}{l}\text { Slight vacuolar-type interface dermatitis with occasional } \\
\text { necrotic keratinocytes and no eosinophils. }\end{array}$ & ND & ND & [48] \\
\hline $\begin{array}{l}42 \mathrm{M} \\
32 \mathrm{~F}\end{array}$ & mean: $19.6 \mathrm{y}$ & $\begin{array}{l}\text { Erythematous papules }(76.4 \%), \\
\text { similar to chilblains and } \\
\text { purpuric macules }(40.54 \%) .\end{array}$ & Hands and feet & 16.15 days & ND & $\begin{array}{l}\text { Lymphocytic perivascular and perieccrine infiltrate with } \\
\text { no vascular occlusion or intravascular thrombi. }\end{array}$ & $\begin{array}{l}\text { positive } \\
(1 \text { in 11) }\end{array}$ & ND & [31] \\
\hline $\begin{array}{c}6 \mathrm{M} \\
6 \mathrm{~F}\end{array}$ & mean: $66.3 \mathrm{y}$ & Itching papular exanthem. & Entire body & 20.4 days & ND & $\begin{array}{l}\text { Superficial perivascular inflammation with eosinophils } \\
(n=1) \text { and lichenoid pattern with eosinophils }(n=1) .\end{array}$ & positive & $\mathrm{ND}$ & [39] \\
\hline $1 \mathrm{~F}$ & $50 \mathrm{y}$ & $\begin{array}{l}\text { Small, monomorphic vesicles of } \\
2-3 \mathrm{~mm} \text { diameter, often } \\
\text { excoriated at their top. }\end{array}$ & $\begin{array}{l}\text { Trunk, upper } \\
\text { limbs, face }\end{array}$ & 21 days & 10 days & $\begin{array}{l}\text { Acantholysis, intraepidermal vesicle, suprabasal clefts, } \\
\text { prominent, "pomegranate-like” dyskeratosis, suspected } \\
\text { nuclear viral inclusions and multinucleated cells. }\end{array}$ & positive & ND & [58] \\
\hline $1 \mathrm{~F}$ & $70 y$ & $\begin{array}{l}\text { Diffuse, pruritic } \\
\text { pustular eruption. }\end{array}$ & Face, trunk and upper limbs & 21 days & 30 days & $\begin{array}{l}\text { Subcorneal pustules with mild focal acanthosis and } \\
\text { spongiosis, neutrophilic exocytosis, sparse keratinocyte } \\
\text { necrosis, and a perivascular lymphocytic infiltrate with } \\
\text { rare neutrophils and eosinophils. }\end{array}$ & ND & ND & [36] \\
\hline $\begin{array}{l}153 \mathrm{M} \\
222 \mathrm{~F}\end{array}$ & mean: $49 y$ & $\begin{array}{l}\text { Maculopapular }(47 \%), \\
\text { pseudochilblain }(19 \%), \\
\text { urticarial }(19 \%), \\
\text { vesicular }(9 \%) \text { and } \\
\text { livedo/necrosis }(6 \%) \\
\end{array}$ & $\begin{array}{l}\text { Extremities, Hands and feet, } \\
\text { trunk, limbs and acral areas }\end{array}$ & $\begin{array}{l}\text { before, at the same time or } \\
\text { after }\end{array}$ & $\begin{array}{c}8.6 \text { days } \\
12.7 \text { days } \\
6.8 \text { days } \\
10.4 \text { days } \\
\text { ND } \\
\end{array}$ & No biopsy & $\begin{array}{l}\text { positive } \\
(234 \text { in } \\
375)\end{array}$ & ND & [41] \\
\hline $\begin{array}{l}8 \mathrm{~F} \\
6 \mathrm{M}\end{array}$ & $\begin{array}{l}11 \text { children } \\
\text { mean: } 14 \text { y } \\
3 \text { adults } \\
\text { mean: } 29 \text { y }\end{array}$ & $\begin{array}{c}\text { Perniosis-like } \\
\text { erythemato-violaceous papules } \\
\text { and macules with possible } \\
\text { bullous evolution or digital } \\
\text { swelling or erythemato-papular } \\
\text { targetoid lesions }\end{array}$ & $\begin{array}{l}\text { Feet in eight cases, hands in } \\
\text { four cases, both sites in two } \\
\text { cases (elbow in one case) }\end{array}$ & ND & $2-4$ weeks & $\begin{array}{l}\text { Acral lesions, a diffuse dense lymphoid infiltrate of the } \\
\text { superficial and deep dermis, as well as hypodermis, with } \\
\text { a prevalent perivascular pattern and signs of endothelial } \\
\text { activation/Targetoid lesions of the elbows, mild } \\
\text { superficial perivascular dermatitis. }\end{array}$ & $\begin{array}{l}\text { negative } \\
\text { (in 5) }\end{array}$ & ND & [25] \\
\hline 18 & ND & $\begin{array}{c}\text { Erythematous rash }(n=14) \text {, } \\
\text { widespread urticaria }(n=3) \text { or } \\
\text { varicella-like vesicles }(n=1)\end{array}$ & Trunk & ND & A few days & No biopsy & positive & ND & [24] \\
\hline 5 & ND & $\begin{array}{l}\text { Erythematous rash }(n=2), \\
\text { urticaria }(n=2) \text { and herpes } \\
\text { lesion }(n=1)\end{array}$ & $\begin{array}{l}\text { Face and the upper body } \\
(n=4) \text {, mouth }(n=1)\end{array}$ & ND & $1-6$ days & No biopsy & positive & ND & [11] \\
\hline $1 \mathrm{~F}$ & $74 \mathrm{y}$ & $\begin{array}{l}\text { Livedoid macules initially, then } \\
\text { digital infarcts and ischemic } \\
\text { necrosis }\end{array}$ & Third fingertip of the left hand & ND & ND & No biopsy & positive & ND & [32] \\
\hline
\end{tabular}


Table 1. Cont.

\begin{tabular}{|c|c|c|c|c|c|c|c|c|c|}
\hline \multirow{2}{*}{$\mathrm{Nb} \& \mathrm{Sex}$} & \multirow{2}{*}{ Age } & \multirow{2}{*}{ Clinical Features } & \multirow{2}{*}{ Localization of Skin Lesions } & \multirow{2}{*}{ Time from 1st Symptoms } & \multirow{2}{*}{ Mean Duration } & \multirow{2}{*}{ Histopathological Features } & \multicolumn{2}{|c|}{ SARS-CoV-2 RT-PCR } & \multirow{2}{*}{ Ref } \\
\hline & & & & & & & Swab & Skin Biopsy & \\
\hline \multirow{2}{*}{$2 \mathrm{~F}$} & $27 y$ & Red-purple papules & $\begin{array}{l}\text { Dorsal side of } \\
\text { fingers bilaterally }\end{array}$ & \multirow{2}{*}{ ND } & \multirow{2}{*}{ ND } & \multirow{2}{*}{ No biopsy } & \multirow{2}{*}{ positive } & \multirow{2}{*}{ ND } & \multirow{2}{*}{ [2] } \\
\hline & $35 \mathrm{y}$ & Diffuse erythema & $\begin{array}{l}\text { Subungual area of the } \\
\text { right thumb }\end{array}$ & & & & & & \\
\hline $1 \mathrm{~F}$ & $19 \mathrm{y}$ & erythemato-violaceous plaques & Feet and toes & ND & ND & No biopsy & ND & ND & [6] \\
\hline $41 \mathrm{M}$ & mean: $58 \mathrm{y}$ & $\begin{array}{l}\text { AGA: } 29(71 \%) \text { with clinically } \\
\text { significant AGA and } 16(39 \%) \\
\text { with severe AGA }\end{array}$ & Scalp & ND & ND & No biopsy & ND & ND & [9] \\
\hline 2 & ND & Skin rash & ND & $\mathrm{ND}$ & ND & No biopsy & positive & $\mathrm{ND}$ & {$[10]$} \\
\hline 1 & ND & Dengue-like petechial rash. & ND & ND & ND & No biopsy & positive & ND & {$[16]$} \\
\hline $1 \mathrm{~F}$ & ND & $\begin{array}{l}\text { Painful erythematous patches } \\
\text { with residual purpura. }\end{array}$ & Trunk and hips & $\mathrm{ND}$ & ND & $\begin{array}{l}\text { Blood extravasation and neutrophilic perivascular } \\
\text { inflammation with prominent karyorrhexis. }\end{array}$ & positive & $\mathrm{ND}$ & {$[49]$} \\
\hline 4 & ND & $\begin{array}{c}\text { Erythematous-violaceous } \\
\text { macules, sometimes more } \\
\text { necrotic in appearance, even } \\
\text { with blistering lesions. } \\
\end{array}$ & $\begin{array}{l}\text { Soles of the feet, finger and/or } \\
\text { toe pads or periungual location }\end{array}$ & ND & ND & No biopsy & ND & ND & {$[26]$} \\
\hline 2 & ND & Urticaria & ND & ND & ND & No biopsy & positive & ND & {$[28]$} \\
\hline $\begin{array}{l}4 \mathrm{M} \\
3 \mathrm{~F}\end{array}$ & mean: $59 \mathrm{y}$ & $\begin{array}{l}\text { Cyanosis, skin bulla and dry } \\
\text { gangrene. }\end{array}$ & Finger/Toe & $\mathrm{ND}$ & ND & No biopsy & ND & ND & {$[29]$} \\
\hline $1 \mathrm{M}$ & $17 \mathrm{y}$ & Chilblain-like lesions & Toes of both feet and heels & ND & ND & No biopsy & negative & ND & {$[35]$} \\
\hline $\begin{array}{c}10 \mathrm{M} \\
7 \mathrm{~F}\end{array}$ & mean: $32 \mathrm{y}$ & $\begin{array}{l}\text { Ped-violaceous, edematous, } \\
\text { rarely necrotic lesions. }\end{array}$ & Toes, feet and fingers & ND & ND & $\begin{array}{l}\text { Diffuse upper dermal edema and a dense dermal } \\
\text { (perivascular and peri-eccrine sweat gland) lymphocytic } \\
\text { infilltrate, endothelial cell swelling and extravasated red } \\
\text { blood cells, thrombi, fibrin and IgM deposits in vessels. }\end{array}$ & negative & negative & {$[42]$} \\
\hline $\begin{array}{l}7 \mathrm{M} \\
3 \mathrm{~F}\end{array}$ & mean: $7.5 \mathrm{y}$ & Polymorphic rash & ND & $\mathrm{ND}$ & ND & No biopsy & $\begin{array}{l}2 \text { positive } \\
8 \text { negative }\end{array}$ & ND & {$[44]$} \\
\hline 8 & ND & $\begin{array}{c}\text { Maculopapular eruption/ } \\
\text { exanthema/Purpuric } \\
\text { maculo-papulo-vesicular } \\
\text { rash/Papular } \\
\text { erythematousexanthema/Severe } \\
\text { macular haemorrhagic eruption. }\end{array}$ & $\begin{array}{l}\text { Trunk/Trunk and limbs/ } \\
\text { Trunk/Extremities }\end{array}$ & ND & ND & $\begin{array}{l}\text { Dyskeratotic cells, ballooning multinucleated cells and } \\
\text { sparse necrotic keratinocytes with lymphocytic } \\
\text { satellitosis/Nests of Langerhans cells within the } \\
\text { epidermis and difffuse telangiectatic blood vessels in the } \\
\text { upper dermis/Perivascular spongiotic dermatitis and a } \\
\text { dense perivascular lymphocytic infiltration eosinophilic } \\
\text { rich around the swollen blood vessels with extravasated } \\
\text { erythrocytes/Edematous dermis with many eosinophils, } \\
\text { cuffs of lymphocytes around blood vessels in a a } \\
\text { lymphocytic vasculitis/Intravascular microthrombi in the } \\
\text { small dermal vessels. }\end{array}$ & ND & ND & {$[45]$} \\
\hline $1 \mathrm{M}$ & $68 \mathrm{y}$ & $\begin{array}{l}\text { Morbilliform rash/Purpuric } \\
\text { lesions/Ulcerated, purpuric } \\
\text { plaque with } \\
\text { retiform-livedoid borders. }\end{array}$ & Trunk/Feet/Buttocks & ND & ND & $\begin{array}{l}\text { Groups of apoptotic keratinocytes in the } \\
\text { epidermis/ND/Features consistent with a } \\
\text { thrombotic vasculopathy. }\end{array}$ & ND & ND & {$[46]$} \\
\hline $1 \mathrm{~F}$ & $72 \mathrm{y}$ & $\begin{array}{l}\text { Erythematous and slightly } \\
\text { edematous patches/Isolated } \\
\text { typical target lesions. }\end{array}$ & $\begin{array}{l}\text { Trunk and upper and lower } \\
\text { limbs/Both thighs }\end{array}$ & ND & ND & $\begin{array}{l}\text { Mixed perivascular and interstitial infiltrate, including } \\
\text { lymphocytes, granulocytes, histiocytes, plasma cells and } \\
\text { mast cells. }\end{array}$ & positive & ND & {$[50]$} \\
\hline
\end{tabular}


Table 1. Cont.

\begin{tabular}{|c|c|c|c|c|c|c|c|c|c|}
\hline \multirow{2}{*}{$\mathrm{Nb} \& \mathrm{Sex}$} & \multirow{2}{*}{ Age } & \multirow{2}{*}{ Clinical Features } & \multirow{2}{*}{ Localization of Skin Lesions } & \multirow{2}{*}{ Time from 1st Symptoms } & \multirow{2}{*}{ Mean Duration } & \multirow{2}{*}{ Histopathological Features } & \multicolumn{2}{|c|}{ SARS-CoV-2 RT-PCR } & \multirow{2}{*}{ Ref. } \\
\hline & & & & & & & Swab & Skin Biopsy & \\
\hline $1 \mathrm{~F}$ & $29 \mathrm{y}$ & $\begin{array}{c}\text { Pruriginous and painful } \\
\text { subcutaneous nodular lesions. }\end{array}$ & $\begin{array}{l}\text { Legs, thighs, forearms and left } \\
\text { shoulder }\end{array}$ & $\mathrm{ND}$ & ND & $\begin{array}{l}\text { Lobular panniculitis with lymphocytes, histiocytes and } \\
\text { numerous eosinophils. }\end{array}$ & positive & $\mathrm{ND}$ & {$[51]$} \\
\hline $1 \mathrm{~F}$ & $68 \mathrm{y}$ & Painful vesicular rash. & $\begin{array}{l}\text { Left side of the chest and nape } \\
\text { of the neck }\end{array}$ & ND & ND & No biopsy & positive & ND & {$[52]$} \\
\hline $1 \mathrm{M}$ & $16 y$ & $\begin{array}{l}\text { Painful dusky erythematous } \\
\text { plaques. }\end{array}$ & Posterior scalp & ND & ND & $\begin{array}{l}\text { Necrosis of the epidermis and most of the dermis with } \\
\text { extravasation of erythrocytes and fibrin thrombi in the } \\
\text { capillaries, as well as infiltration of neutrophils with } \\
\text { nuclear debris in vessel walls. }\end{array}$ & negative & negative & {$[56]$} \\
\hline $\begin{array}{l}8 \mathrm{M} \\
8 \mathrm{~F}\end{array}$ & $\begin{array}{c}\text { mean: } 10 \\
(4.5 \text { to } 12.5)\end{array}$ & $\begin{array}{l}\text { Maculopapular rash in } 13 \\
\text { (81\%) patients. }\end{array}$ & ND & ND & ND & No biopsy & $\begin{array}{l}\text { positive } \\
\text { (11 in 16) }\end{array}$ & ND & {$[57]$} \\
\hline
\end{tabular}


We still have a lot to learn about the cutaneous manifestations associated with this disease, and there are currently more questions than answers. It is still unclear what percentage of COVID-19 patients develops cutaneous eruptions. Although $20.4 \%$ of patients (18 out of 88 ) in an Italian cohort developed cutaneous abnormalities [24], they were present in only $1.8 \%$ (2 out of 1099 patients) in a Chinese cohort [10].

\section{Methods}

A literature search using the following strategy was performed on the PubMed database to identify eligible articles: (COVID* or coronavirus* or SARS-CoV-2*) and (dermatol* or skin* or cutaneous*). The publication date was limited to December 2019 onward. A total of 112 papers were identified in the initial search. Abstracts and full-texts of all articles were then reviewed. Reports on different cutaneous manifestations associated with COVID-19 were included in this review (67 in total, 57 of which are listed in Table 1).

\section{Results and Discussion}

\subsection{Clinical Manifestations}

Clinical manifestations are as follows (see Table 1): generalized or localized rash (erythematous, papulovesicular, maculopapular, petechial, morbilliform, symmetrical drug-related intertriginous and flexural exanthema (SDRIFE)-like, digitate papulosquamous pityriasis rosea-like), generalized urticaria, varicelliform rash, herpes lesions (zoster), purpuric lesions (retiform purpura), livedoid lesions (livedo reticularis, livedo racemosa), acro-ischemic lesions (dry gangrene, blisters, cyanosis), erythema multiforme-like, chilblain-like lesions (COVID toes) and other lesions such as urticarial vasculitis, acute generalized exanthematous pustulosis (AGEP)-like rash, eosinophilic panniculitis, COVID mask, periorbital dyschromia, oral ulcers and COVID red half-moon nail sign. In addition, a high frequency of androgenetic alopecia has been observed in COVID-19 patients. Based on these clinical manifestations, an algorithm for the classification of COVID-19 rashes has been proposed [60].

In a recent Spanish study including 375 cases, five clinical patterns were described [41]: maculopapular eruptions (47\%), acral areas of erythema with vesicles or pustules (pseudochilblain) $(19 \%)$, urticarial lesions (19\%), other vesicular eruptions (9\%) and livedo or necrosis (6\%).

The lesions are mainly localized in the trunk and extremities (hands and feet), sparing the face; however, lesions located on the face, neck, mouth and axillary folds have also been reported.

The majority of patients were male, aged between 4.5 and 89 years. A minority of patients were children (between 4.5 and 14 years) presenting with acral, chilblain-like lesions, papulo-vesicular eruptions on the trunk or pediatric inflammatory multisystem syndrome.

The mean duration of the lesions was a few days, but some lasting as little as $20 \mathrm{~min}$ and others as long as four weeks have been reported. The mean latency time (i.e., time to develop skin lesions after the appearance of the first typical symptoms of COVID-19) in the majority of cases was between 1 and 14 days; however, in some patients, lesions appeared 2 to 5 days before the onset of COVID-19 symptoms.

In the table, we have classified all reported cases according to the time of occurrence of skin lesions. In some patients, lesions appeared 2 to 5 days before the onset of COVID-19 symptoms; one such case involved an 8 year-old. The types of skin lesions in these patients were similar to those appearing up to 7 days after the onset of the first symptoms of COVID-19; this is consistent with a viral rash. In contrast, lesions appearing beyond the 7th day of ongoing COVID-19 are more vascular in nature.

COVID-19 is less frequent in children than adults $(<1 \%)$, with a milder course; however, cases of pediatric inflammatory multisystem syndrome with features resembling atypical Kawasaki disease occurring several weeks after SARS-CoV-2 infection have recently been reported in children in the UK, as well as in Italy, France, Switzerland and the USA (Kawa-COVID-19) [57]. Clinical presentation includes fever, variable rash, conjunctivitis and abdominal pain, progressing to hemodynamic shock 
with severe myocardial involvement. Severe disease, with the need for intensive care due to myocarditis, occurred in almost half of all reported cases, with a higher risk of poor outcome for patients older than 5 years of age, and particularly for teenagers. A recent study from Italy reported a 30-fold increase in the rate of Kawasaki-like presentation during the COVID-19 pandemic among children; in many cases, nasopharyngeal swabs taken from these children were negative for COVID-19, and the association with COVID-19 infection is unclear [44].

\subsection{Histopathological Features}

Histopathological features have been reported in only a minority of patients in these articles (Table 1).

\subsubsection{Maculopapular Eruptions}

Maculopapular eruptions show superficial perivascular dermatitis with slight lymphocytic exocytosis, swollen thrombosed vessels with neutrophils, eosinophils and nuclear debris/superficial and deep perivascular dermatitis with cuffs of lymphocytes surrounding blood vessels in a vasculitic pattern/superficial perivascular vesicular dermatitis, focal acantholytic suprabasal clefts, dyskeratotic and ballooning herpes-like keratinocytes and swollen vessels with dense lymphocyte infiltration mixed with rare eosinophils in the dermis.

\subsubsection{Varicella-Like Papulovasicular Exanthem}

Varicella-like papulovasicular exanthems display vacuolar degeneration of the basal layer with multinucleate, hyperchromatic keratinocytes and dyskeratotic cells with no inflammatory infiltrate. According to Mahé et al., these exanthems histologically show acantholysis, intraepidermal vesicles with suprabasal clefts, prominent, "pomegranate-like" dyskeratosis and suspected viral inclusions in multinucleated cells. The authors of that report proposed the term "COVID-19-associated acantholytic rash", rather than "varicella-like rash" [58].

\subsubsection{Urticarial Lesions}

Urticarial lesions show perivascular infiltrate of lymphocytes, some eosinophils and upper dermal edema. Urticarial vasculitis lesions show blood extravasation and neutrophilic perivascular inflammation with prominent karyorrhexis, some macrophages with a cytoplasm full of nuclear debris and endothelial swelling, necrosis and fibrin deposition. Some urticarial lesions show slight vacuolar-type interface dermatitis with occasional necrotic keratinocytes with no eosinophils, consistent with an erythema multiforme-like pattern.

\subsubsection{Acral Chilblain-Like Lesions}

In acral chilblain-like lesions, a diffuse dense lymphoid infiltrate of the superficial and deep dermis, as well as hypodermis, with a prevalent perivascular pattern and signs of endothelial activation, are observed.

\subsubsection{Purpuric and Livedoid Lesions}

Purpuric and livedoid lesions show thrombogenic vasculopathy accompanied by striking and extensive deposition of C5b-9 and C4d within the microvasculature.

\subsubsection{Pityriasis Rosea-Like Lesions}

In pityriasis rosea-like lesions, there is mild diffuse spongiosis in the epidermis and rounded spongiotic vesicles containing aggregates of lymphocytes and Langerhans cells, as well as mild papillary edema and lymphohistiocytic infiltrate in the dermis. 


\subsubsection{Kawasaki-Like Lesions}

In Kawasaki-like lesions, findings consistent with leukocytoclastic vasculitis, including necrosis of the epidermis and most of the dermis with extravasation of erythrocytes and fibrin thrombi in the capillaries, as well as infiltration of neutrophils with nuclear debris in vessel walls, and C3 and IgA deposition in a vascular pattern in direct immunofluorescence, are observed.

\subsubsection{Subcutaneous Lesions}

Subcutaneous lesions show a predominantly lobular panniculitis with lymphocytes, histiocytes and many eosinophils, consistent with an eosinophilic panniculitis.

\subsubsection{Pustular Lesions}

Pustular lesions show a subcorneal pustule with mild focal acanthosis and spongiosis, neutrophilic exocytosis, sparse keratinocyte necrosis and a perivascular lymphocytic infiltrate with rare neutrophils and eosinophils, consistent with acute generalized exanthematous pustulosis.

In a recent report, the postmortem histology of COVID-19 patients revealed lymphocytic endotheliitis in lung, heart, kidney, liver and small intestine, a pathological picture reminiscent of what is seen in skin lesions, suggesting that SARS-CoV-2 infection facilitates the induction of endothelial inflammation in several organs as a direct consequence of viral involvement and of host inflammatory response [61].

The histopathological features of these lesions also vary, corresponding to the diversity of clinical manifestations. In maculopapular lesions, it is sometimes quite difficult to differentiate a drug reaction from a viral infection. However, the presence of multinucleated ballooning cells suggests a cytopathic effect, lending weight to the hypothesis that the lesions are due to COVID-19. For varicella-like acantholytic lesions, Grover's disease should be eliminated by the presence of endothelial swelling and vascular damage or extensive epidermal necrosis, and a herpes infection by immunohistochemistry and cultures. The histology of chilblain lesions are quite characteristic, with dermal edema and deep lymphocytic vasculitis, and purpuric and livedoid lesions show vascular thrombosis. In Kawasaki-like lesions and urticarial vasculitis, leukocytoclastic vasculitis is observed. Other lesions such as urticaria, pityriasis rosea-like, subcutaneous and pustular lesions do not seem to be specific. These features underline the nature of epidermal (acantholysis, multinucleated ballooning keratinocytes, dyskeratosis, necrosis) and dermal vascular (lymphocytic vasculitis, endotheliitis) lesions-and in severe cases, microvascular injury and thrombosis-associated with COVID-19, and provide important clues to their pathological mechanisms.

\subsection{Potential Pathological Mechanisms}

The pathological mechanisms of skin lesions in COVID-19 patients remain poorly understood. Cutaneous manifestations in COVID-19 may be classified into two major groups regarding their pathomechanisms [62]:

(1) clinical features similar to viral exanthems (an immune response to viral nucleotides)

(2) cutaneous eruptions secondary to systemic consequences caused by COVID-19 (especially vasculitis and thrombotic vasculopathy).

The possible actions of SARS-CoV-2 on human skin and the resulting potential dermatological manifestations can be summarized as follows [63].

SARS-CoV-2 is a single-stranded RNA virus composed of 16 nonstructural proteins (NSP 1-16) with specific roles in the replication of coronaviruses (CoVs). For example, NSP3 has the ability to block the host's innate immune response and promote cytokine expression, while NSP5 can inhibit interferon (IFN) signaling, and NSP16 avoids MAD5 (melanoma differentiation-associated gene 5) recognition, depressing innate immunity. 
Some studies have shown direct $\mathrm{T}$ cell viral infection by the detection SARS-like viral particles and SARS-CoV-2 RNA in T lymphocytes.

In a subset of patients, overactive immune responses may induce immunopathological conditions, or "cytokine storm" (i.e., an increase in pro-inflammatory cytokines, in particular, IL-6); these cytokines could reach the skin and stimulate dermal dendritic cells, macrophages, mast cells, lymphocytes and neutrophils, and promote eruptions such as erythema, urticarial lesions, vesicles and others (JAK inhibitors for IL-6).

Complement activation (C5b-9 and C4d) by SARS-CoV-2 spike glycoproteins has been shown in retiform purpura [18]. In pseudochilblain and purpuric lesions, an obliterative microangiopathy consisting of endothelial and intensive myointimal growth with complement activation has been observed. This mechanism, together with increased vascular permeability, could contribute to obliterative vascular lumen and hemorrhage in COVID-19 patients [64].

Aerosolized uptake of SARS-CoV-2 leads to infection of the functional receptor angiotensin-converting enzyme (ACE) type II (ACE2)-expressing target cells such as alveolar type 2 or other unknown target cells. ACE2 is present in the skin in the basal layer of the epidermis, in endothelial cells of dermal blood vessels and in eccrine adnexal tissue [65]; a direct pathogenic effect of the virus in the epidermis via ACE2, leading to acantholysis and dyskeratosis, has been proposed [58]. COVID-19-endotheliitis via ACE2 could explain the systemic impaired microcirculatory function in different vascular beds and their clinical sequelae in patients with COVID-19 [62]. SARS-CoV-2 was shown to be absent in only four studied lesional skin biopsy samples (Table 1). However, in two recent reports, its presence was confirmed by immunohistochemistry in the endothelial cells of chilblain lesions, suggesting a causal relationship between the lesions and SARS-CoV-2 [66,67]. In one of them SARS-CoV-2 particles were found in the cytoplasm of endothelial cells by electron microscopy [66]. Endothelial damage induced by the virus could be the key mechanism in the pathogenesis of COVID-19 chilblains, and perhaps also in a group of patients severely affected by COVID-19 presenting with microangiopathic damage [66].

In order for the virus to attach (spike protein, S) to ACE2, activation by TMPRSS2, a type II transmembrane serine protease, is needed. The TMPRSS2 gene is located on human chromosome 21; one of its significant features is that several androgen receptor elements (AREs) are located upstream of the transcription start site. The first intron COVID-19 could affect males more than females due to the relationship between TMPRSS2 and androgen levels; the greater prevalence of COVID-19 in males in Spain offers a potential clue to the role of androgens in increasing COVID-19 severity, due to the higher prevalence of androgenetic alopecia among patients [9].

A better understanding of the clinical, histopathological and pathogenetic aspects of COVID-19 in different organs, including skin, will help guide early diagnoses and treatment of this new and fatal human disease with intriguing cutaneous manifestations.

Author Contributions: G.K. and A.K. contributed to the acquisition, analysis and interpretation of data for the work, participated in original draft preparation. J.-H.S. made substantial contributions to the conception and design of the work; participated in original draft preparation, revising it critically for important intellectual content. All authors have read and agreed to the published version of the manuscript.

Funding: This research received no external funding.

Acknowledgments: In this section you can acknowledge any support given which is not covered by the author contribution or funding sections. This may include administrative and technical support, or donations in kind (e.g., materials used for experiments).

Conflicts of Interest: The authors declare no conflict of interest.

\section{References}

1. Kaya, G.; Kaya, A.; Saurat, J.H. Covid-19 and Skin Gazette. Skin lesions in Covid-19. Clinical and histopathological features: Review of the literature. Derm. Helv. 2020, 32, 18-20. 
2. Alramthan, A.; Aldaraji, W. Two cases of COVID-19 presenting with a clinical picture resembling chilblains: First report from the Middle East. Clin. Exp. Dermatol. 2020. [CrossRef] [PubMed]

3. Estébanez, A.; Pérez-Santiago, L.; Silva, E.; Guillen-Climent, S.; García-Vázquez, A.; Ramón, M.D. Cutaneous manifestations in COVID-19: A new contribution. J. Eur. Acad. Dermatol. Venereol. 2020, 34, e250-e251. [CrossRef] [PubMed]

4. Fernandez-Nieto, D.; Ortega-Quijano, D.; Segurado-Miravalles, G.; Pindado-Ortega, C.; Prieto-Barrios, M.; Jimenez-Cauhe, J. Comment on: Cutaneous manifestations in COVID-19: A first perspective. Safety concerns of clinical images and skin biopsies. J. Eur. Acad. Dermatol. Venereol. 2020, 34. [CrossRef] [PubMed]

5. Fernandez-Nieto, D.; Jimenez-Cauhe, J.; Suarez-Valle, A.; Moreno-Ar-Rones, O.M.; Saceda-Corralo, D.; Arana-Raja, A.; Ortega-Quijano, D. Characterization of acute acro-ischemic lesions in non-hospitalized patients: A case series of 132 patients during the Covid-19 outbreak. J. Am. Acad. Dermatol 2020. [CrossRef]

6. Frieyro, M. El coronavirus o Covid-19 puede provocar síntomas cutáneos en niños y adolescentes. Unidad de Dermatología HC Marbella. Available online: https://www.hcmarbella.com/es/el-coronavirus-o-Covid-19puede-provocar-sintomas-cutaneos-en-ninos-y-adolescentes/ (accessed on 9 April 2020).

7. Genovese, G.; Colonna, C.; Marzano, A. Varicella-like exanthem associated with COVID-19 in an 8-year-old girl: A diagnostic clue? Pediatr. Dermatol. 2020. [CrossRef]

8. Gianotti, R.; Veraldi, S.; Recalcati, S.; Cusini, M.; Ghislanzoni, M.; Boggio, F.; Fox, L.P. Cutaneous Clinico-Pathological Findings in three COVID-19-Positive Patients Observed in the Metropolitan Area of Milan, Italy. Acta. Derm. Venereol. 2020. [CrossRef]

9. Goren, A.; Vaño-Galván, S.; Wambier, C.G.; McCoy, J.; Gomez-Zubiaur, A.; Moreno-Arrones, O.M.; Shapiro, J.; Sinclair, R.D.; Gold, M.H.; Kovacevic, M.; et al. A preliminary observation: Male pattern hair loss among hospitalized COVID-19 patients in Spain-A potential clue to the role of androgens in COVID-19 severity. J. Cosmet. Dermatol. 2020. [CrossRef]

10. Guan, W.; Ni, Z.; Hu, Y.; Liang, W.H.; Ou, C.Q.; He, J.X.; Liu, L.; Shan, H.; Lei, C.-L.; Hui, D.S.C.; et al. Clinical characteristics of coronavirus disease 19 in China. N. Engl. J. Med. 2020. [CrossRef]

11. Hedou, M.; Carsuzaa, F.; Chary, E.; Hainaut, E.; Cazenave-Roblot, F.; Regnault, M.M. Comment on “Cutaneous manifestations in COVID-19: A first perspective" by Recalcati S. J. Eur. Acad. Dermatol. Venereol. 2020. [CrossRef]

12. Henry, D.; Ackerman, M.; Sancelme, E.; Finon, A.; Esteve, E. Urticarial eruption in COVID-19 infection. J. Eur. Acad. Dermatol. Venereol. 2020, 34, e244-e245. [CrossRef]

13. Hoenig, L.J.; Pereira, F.A. Eruption as a clinical manifestation of COVID-19: Photographs of a patient. Clin. Dermatol. 2020. [CrossRef]

14. Hunt, M.; Koziatek, C. A Case of COVID-19 Pneumonia in a Young Male with Full Body Rash as a Presenting Symptom. Clin. Pr. Cases Emerg. Med. 2020, 4, 219-221. [CrossRef]

15. Jimenez-Cauhe, J.; Ortega-Quijano, D.; Prieto-Barrios, M.; Moreno-Arrones, O.M.; Fernandez-Nieto, D. Reply to "COVID-19 can present with a rash and be mistaken for dengue": Petechial rash in a patient with COVID-19 infection. J. Am. Acad. Dermatol. 2020. [CrossRef] [PubMed]

16. Joob, B.; Wiwanitkit, V. Covid-19 can present with a rash and be mistaken for Dengue. J. Am. Acad. Dermatol. 2020, 82, e177. [CrossRef] [PubMed]

17. Kluytmans, M.; Buiting, A.; Pas, S.; Bentvelsen, R.; van den Bijllaardt, W.; van Oudheusden, A.; van Rijen, M.; Verweij, J.; Koopmans, M.; Kluytmans, J. SARS-CoV-2 infection in 86 healthcare workers in two Dutch hospitals in March 2020. medRxiv 2020. [CrossRef]

18. Magro, C.; Mulvey, J.J.; Berlin, D.; Nuovo, G.; Salvatore, S.; Harp, J.; Baxter-Stoltzfus, A.; Laurence, J. Complement associated microvascular injury and thrombosis in the pathogenesis of severe COVID-19 infection: A report of five cases. Transl. Res. 2020, 220, 1-13. [CrossRef] [PubMed]

19. Mahé, A.; Birckel, E.; Krieger, S.; Merklen, C.; Bottlaender, L. A distinctive skin rash associated with coronavirus disease 2019? J. Eur. Acad. Dermatol. Venereol. 2020, 34. [CrossRef]

20. Manalo, I.F.; Smith, M.K.; Cheeley, J.; Jacobs, R. A Dermatologic Manifestation of Covid-19: Transient Livedo Reticularis. J. Am. Acad. Dermatol. 2020. [CrossRef]

21. Marzano, A.V.; Genovese, G.; Fabbrocini, G.; Pigatto, P.; Monfrecola, G.; Piraccini, B.M.; Veraldi, S.; Rubegni, P.; Cusini, M.; Caputo, V.; et al. Varicella-like exanthem as a specific Co- vid-19-associated skin manifestation: Multicenter case series of 22 patients. J. Am. Acad. Dermatol. 2020. [CrossRef] 
22. Mazzotta, F.; Troccoli, T. Acute acro-ischemia in the child at the time of Covid-19. Eur. J. Ped. Dermatol. 2020, $30,71-74$.

23. Najarian, D.J. Morbilliform exanthem associated with COVID-19. JAAD Case Rep. 2020, 6, 493-494. [CrossRef] [PubMed]

24. Recalcati, S. Cutaneous manifestations in Covid-19: A first perspective. J. Eur. Acad. Dermatol. Venereol. 2020. [CrossRef] [PubMed]

25. Recalcati, S.; Barbagallo, T.; Frasin, L.; Prestinari, F.; Cogliardi, A.; Provero, M.; Dainese, E.; Vanzati, A.; Fantini, F. Acral cutaneous lesions in the time of COVID-19. J. Eur. Acad. Dermatol. Venereol. 2020. [CrossRef]

26. Taberner-Ferrer, R. ¿COVID19 en forma de sabañones? DermaPixel. 2020. Available online: https: //www.dermapixel.com/2020/04/covid19-en-forma-de-sabanones.html (accessed on 16 April 2020).

27. Van Damme, C.; Berlingin, E.; Saussez, S.; Accaputo, O. Acute urticaria with pyrexia as the first manifestations of a COVID-19 infection. J. Eur. Acad. Dermatol. Venereol. 2020. [CrossRef]

28. Zhang, J.-J.; Dong, X.; Cao, Y.-Y.; Yuan, Y.-D.; Yang, Y.-B.; Yan, Y.-Q.; Akdis, C.A.; Gao, Y.-D. Clinical characteristics of 140 patients infected with SARS-CoV-2 in Wuhan, China. Allergy 2020, 14238. [CrossRef]

29. Zhang, Y.; Cao, W.; Xiao, M.; Li, Y.J.; Yang, Y.; Zhao, J.; Zhou, X.; Jiang, W.; Zhao, Y.Q.; Zhang, S.Y.; et al. Clinical and coagulation characteristics of 7 patients with critical COVID-2019 pneumonia and acro-ischemia. Zhonghua Xue Ye Xue Za Zhi 2020, 41, E006.

30. Sanchez, A.; Sohier, P.; Benghanem, S.; L'Honneur, A.-S.; Rozenberg, F.; Dupin, N.; Garel, B. Digitate Papulosquamous Eruption Associated With Severe Acute Respiratory Syndrome Coronavirus 2 Infection. JAMA Dermatol. 2020. [CrossRef]

31. Aguirre, A.S.; Gomar, F.D.L.T.; Rosés-Gibert, P.; Castillo, J.G.; Arcaya, Z.M.D.L.A.D.; Gonzalez-Perez, R. Novel outbreak of acral lesions in times of COVID-19: A description of 74 cases from a tertiary university hospital in Spain. Clin. Exp. Dermatol. 2020. [CrossRef]

32. Balestri, R.; Termine, S.; Rech, G.; Girardelli, C. Late onset of acral necrosis after SARS-CoV-2 infection resolution. J. Eur. Acad. Dermatol. Venereol. 2020. [CrossRef]

33. Cordoro, K.M.; Reynolds, S.D.; Wattier, R.; McCalmont, T.H. Clustered Cases of Acral Perniosis: Clinical Features, Histopathology and Relationship to COVID-19. Pediatr. Dermatol. 2020. [CrossRef] [PubMed]

34. Calvão, J.; Relvas, M.; Pinho, A.; Brinca, A.; Cardoso, J. Acro-ischemia and COVID-19 infection: Clinical and histopathological features. J. Eur. Acad. Dermatol. Venereol. 2020. [CrossRef] [PubMed]

35. Monte Serrano, J.; Cruañes Monferrer, J.; García-Gil, M.F. Acro-ischemic skin lesions during COVID-19 epidemic. Semergen 2020. [CrossRef] [PubMed]

36. Test, E.R.; Vezzoli, P.; Carugno, A.; Raponi, F.; Gianatti, A.; Rongioletti, F.; Sena, P. Acute Generalized Exanthematous Pustulosis with Erythema Multiforme-Like lesions in a COVID-19 woman. J. Eur. Acad. Dermatol. Venereol. 2020. [CrossRef]

37. Neri, I.; Guglielmo, A.; Virdi, A.; Gaspari, V.; Starace, M.; Piraccini, B.M. The red half moon nail sign: A novel manifestation of Coronavirus infection. J. Eur. Acad. Dermatol. Venereol. 2020. [CrossRef]

38. Gaspari, V.; Neri, I.; Misciali, C.; Patrizi, A. COVID-19: How it can look on the skin. Clinical and pathological features in twenty COVID-19 patients observed in Bologna, northeastern Italy. J. Eur. Acad. Dermatol. Venereol. 2020. [CrossRef] [PubMed]

39. Rosell-Díaz, A.; Mateos-Mayo, A.; Nieto-Benito, L.M.; Balaguer-Franch, I.; De, E.H.; Laínez-Nuez, A.; Suárez-Fernández, R.; Bergón-Sendín, M.; Torre-Ruiz, L. Exanthema and eosinophilia in Covid-19 patients: Has viral infection a role in drug induced exanthemas? J. Eur. Acad. Dermatol. Venereol. 2020. [CrossRef]

40. Locatelli, A.; Test, E.R.; Vezzoli, P.; Carugno, A.; Moggio, E.; Consonni, L.; Gianatti, A.; Sena, P. Histologic features of long-lasting chilblain-like lesions in a paediatric COVID-19 patient. J. Eur. Acad. Dermatol. Venereol. 2020. [CrossRef]

41. Casas, C.G.; Català, A.; Hernández, G.C.; Rodríguez-Jiménez, P.; Nieto, D.F.; Lario, A.R.; Fernández, I.N.; Ruiz-Villaverde, R.; Falkenhain-López, D.; Velasco, M.L.; et al. Classification of the cutaneous manifestations of COVID -19: A rapid prospective nationwide consensus study in Spain with 375 cases. Br. J. Dermatol. 2020. [CrossRef] 
42. Kanitakis, J.; Lesort, C.; Danset, M.; Jullien, D. Chilblain-Like Acral Lesions During the COVID-19 Pandemic (“COVID TOES"): Histologic, Immunofluorescence and Immunohistochemical Study of 17 Cases. J. Am. Acad. Dermatol. 2020. [CrossRef]

43. Trellu, L.T.; Kaya, G.; Alberto, C.; Calame, A.; McKee, T.; Calmy, A. Clinicopathologic Aspects of a Papulovesicular Eruption in a Patient With COVID-19. JAMA Dermatol. 2020. [CrossRef] [PubMed]

44. Verdoni, L.; Mazza, A.; Gervasoni, A.; Martelli, L.; Ruggeri, M.; Ciuffreda, M.; Bonanomi, E.; D'Antiga, L. An outbreak of severe Kawasaki-like disease at the Italian epicentre of the SARS-CoV-2 epidemic: An observational cohort study. Lancet 2020, 395, 1771-1778. [CrossRef]

45. Gianotti, R.; Zerbi, P.; Dodiuk-Gad, R.P. Clinical and histopathological study of skin dermatoses in patients affected by COVID-19 infection in the Northern part of Italy. J. Dermatol. Sci. 2020, 98, 141-143. [CrossRef] [PubMed]

46. Young, S.; Fernandez, A.P. Skin manifestations of COVID-19. Clevel. Clin. J. Med. 2020. [CrossRef]

47. Cepeda-Valdes, R.; Carrion-Alvarez, D.; Trejo-Castro, A.; Hernandez-Torre, M.; Salas-Alanis, J. Cutaneous manifestations in COVID-19: Familial cluster of urticarial rash. Clin. Exp. Dermatol. 2020. [CrossRef]

48. Rodríguez-Jiménez, P.; Chicharro, P.; De Argila, D.; Muñoz-Hernández, P.; Llamas-Velasco, M. Urticaria-like lesions in COVID-19 patients are not really urticaria-A case with clinicopathological correlation. J. Eur. Acad. Dermatol. Venereol. 2020. [CrossRef]

49. De Perosanz-Lobo, D.; Fernandez-Nieto, D.; Burgos-Blasco, P.; Selda-Enriquez, G.; Carretero, I.; Moreno, C.; Fernández-Guarino, M. Urticarial vasculitis in COVID-19 infection: A vasculopathy-related symptom? J. Eur. Acad. Dermatol. Venereol. 2020, 8. [CrossRef]

50. Gargiulo, L.; Pavia, G.; Facheris, P.; Valenti, M.; Sacrini, F.; Narcisi, A.; Borroni, R.; Costanzo, A.; Mancini, L.L. A fatal case of COVID-19 infection presenting with an erythema multiforme-like eruption and fever. Dermatol. Ther. 2020, e13779. [CrossRef]

51. Leis-Dosil, V.M.; Vicente, A.S.; Lorido-Cortés, M.M. Paniculitis eosinofílica secundaria a infección por COVID-19. Actas Dermo-Sifiliográficas 2020. [CrossRef]

52. Elsaie, M.L.; Youssef, E.A.; Nada, H.A. Herpes zoster might be an indicator for latent COVID 19 infection. Dermatol. Ther. 2020, e13666. [CrossRef]

53. Conforti, C.; Zalaudek, I.; Giuffrida, R.; Zorat, F.; Grillo, A.; Colapietro, N.; Francica, M.; Di Meo, N. "COVID-Mask": An atypical livedoid manifestation of COVID-19 observed in a northern Italy hospital. Dermatol. Ther. 2020, e13701. [CrossRef]

54. Kalner, S.; Vergilis, I.J. Periorbital erythema as a presenting sign of COVID-19. JAAD Case Rep. 2020. [CrossRef] [PubMed]

55. Ansari, R.; Gheitani, M.; Heidari, F.; Heidari, F. Oral cavity lesions as a manifestation of the novel virus (COVID-19): A letter-to-editor. Oral Dis. 2020. [CrossRef]

56. Schnapp, A.; Abulhija, H.; Maly, A.; Armoni-Weiss, G.; Levin, Y.; Faitatziadou, S.M.; Molho-Pessach, V. Introductory histopathologic findings may shed light on COVID19 pediatric hyperinflammatory shock syndrome. J. Eur. Acad. Dermatol. Venereol. 2020. [CrossRef] [PubMed]

57. Pouletty, M.; Borocco, C.; Ouldali, N.; Caseris, M.; Basmaci, R.; Lachaume, N.; Bensaid, P.; Pichard, S.; Kouider, H.; Morelle, G.; et al. Paediatric multisystem inflammatory syndrome temporally associated with SARS-CoV-2 mimicking Kawasaki disease (Kawa-COVID-19): A multicentre cohort. Ann. Rheum. Dis. 2020. [CrossRef]

58. Mahé, A.; Birckel, E.; Merklen, C.; Lefèbvre, P.; Hannedouche, C.; Jost, M.; Droy-Dupré, L. Histology of skin lesions establishes that the vesicular rash associated with COVID-19 is not "varicella-like". J. Eur. Acad. Dermatol. Venereol. 2020. [CrossRef]

59. Lester, J.; Jia, J.; Zhang, L.; Okoye, G.; Linos, E. Absence of Skin of Colour Images in Publications of COVID-19 Skin Manifestations. Br. J. Dermatol. 2020. [CrossRef]

60. Ortega-Quijano, D.; Jimenez-Cauhe, J.; Selda-Enriquez, G.; Fernandez-Guarino, M.; Fernandez-Nieto, D. Algorithm for the classification of COVID-19 rashes. J. Am. Acad. Dermatol. 2020. [CrossRef]

61. Varga, Z.; Flammer, A.J.; Steiger, P.; Haberecker, M.; Andermatt, R.; Zinkernagel, A.S.; Mehra, M.R.; A Schuepbach, R.; Ruschitzka, F.; Moch, H. Endothelial cell infection and endotheliitis in COVID-19. Lancet 2020, 395, 1417-1418. [CrossRef]

62. Suchonwanit, P.; Leerunyakul, K.; Kositkuljorn, C. Cutaneous manifestations in COVID-19: Lessons learned from current evidence. J. Am. Acad. Dermatol. 2020, 83, e57-e60. [CrossRef] 
63. Criado, P.R.; Abdalla, B.M.Z.; De Assis, I.C.; Mello, C.V.B.D.G.; Caputo, G.C.; Vieira, I.C. Are the cutaneous manifestations during or due to SARS-CoV-2 infection/COVID-19 frequent or not? Revision of possible pathophysiologic mechanisms. Inflamm. Res. 2020, 2, 1-12. [CrossRef]

64. Valtueña, J.; Martínez-García, G.; Ruiz-Sánchez, D.; Garayar-Cantero, M.; Dueñas, C.; Aguado-García, Á.; Paula, J.M.P.d.; López, P.M. Vascular Obliteration Due to Endothelial And Myointimal Growth in COVID-19. Prepr. Res. Sq. 2020. [CrossRef]

65. Hamming, I.; Timens, W.; Bulthuis, M.; Lely, A.T.; Navis, G.; Van Goor, H. Tissue distribution of ACE2 protein, the functional receptor for SARS coronavirus. A first step in understanding SARS pathogenesis. J. Pathol. 2004, 203, 631-637. [CrossRef]

66. Colmenero, I.; Santonja, C.; Alonso-Riaño, M.; Noguera-Morel, L.; Hernández-Martín, A.; Andina, D.; Wiesner, T.; Rodríguez-Peralto, J.L.; Requena, L.; Torrelo, A. SARS-CoV-2 endothelial infection causes COVID-19 chilblains: Histopathological, immunohistochemical and ultrastructural study of 7 paediatric cases. Br. J. Dermatol. 2020. [CrossRef]

67. Santonja, C.; Heras, F.; Núñez, L.; Requena, L. COVID-19 chilblain-like lesion: Immunohistochemical demonstration of SARS-CoV-2 spike protein in blood vessel endothelium and sweat gland epithelium in a PCR-negative patient. Br. J. Dermatol. 2020. [CrossRef]

(C) 2020 by the authors. Licensee MDPI, Basel, Switzerland. This article is an open access article distributed under the terms and conditions of the Creative Commons Attribution (CC BY) license (http://creativecommons.org/licenses/by/4.0/). 